\title{
WACANA KEMADJOEAN DI KELOMPOK ETNIS SUNDA AWAL ABAD 20
}

\author{
Holy Rafika Dhona \\ Program Studi Ilmu Komunikasi-Universitas Islam Indonesia Yogyakarta \\ holy.rafika@gmail.com
}

\begin{abstract}
Kemadjoean (progress) was a key term for all social movement in the early $20^{\text {th }}$ century Dutch East Indies. This article argued that the discourse of progress has no single meaning throughout the Dutch East Indies, but instead, it was practiced differently by people from different cultural communities. This article focuses on how the discourse of progress was negotiated by the Sundanese ethnic group. Using Foucauldian discourse analysis on the texts of Papaes Nonoman Newspaper (1914-1917), this studi found that, besides being interpreted as "an attempt to become Dutch", the notion of progress was understood by the Sundanese specifically as a way to liberate Sundanese culture from the domination of Javanese culture.
\end{abstract}

\begin{abstract}
Abstrak
Kemadjoean menjadi istilah kunci bagi semua gerakan sosial pribumi Hindia Belanda di awal abad 20. Tulisan ini meyakini bahwa wacana kemajuan dipraktikkan berbeda dalam tiap komunitas kultural. Tulisan ini membahas bagaimana kemajuan dipahami, didiskusikan dan dinegosiasikan oleh kelompok etnis Sunda pada dekade awal abad 20. Menggunakan analisis wacana Foucauldian pada teks Surat Kabar Papaes Nonoman (1914-1917), penelitian ini menemukan bahwa selain kemajuan dipahami sebagai 'usaha menjadi Belanda'-sebagaimana umumnya terjadi di Hindia Belanda, kemajuan secara khusus dipahami oleh etnis Sunda sebagai pembebasan budaya Sunda dari dominasi budaya etnis Jawa.
\end{abstract}

Keywords: Progress, Colonialism, Discourse

\section{PENDAHULUAN}

Kebijakan kolonial Belanda atas Hindia mengalami perubahan paling radikal di awal abad 20. Penguasaan Belanda atas teritorial Hindia hampir sempurna dan penjajahan dilakukan dengan tujuan yang berbeda dari masa sebelumnya (Ricklefs. MC, 2001: 193). Hal yang menandai perubahan kebijakan ini adalah pelaksanaan Politik Etis. Efek dari perubahan kebijakan ini, terutama di daerah Jawa dan Minangkabau, memunculkan usaha-usaha penyadaran mengenai nasib pribumi melalui organisasi-organisasi kebangsaan misalnya Boedi Oetomo pada 1908, Sarekat Dagang Islam pada 1911, dan organisasi kebangsaan lain.

Tahun 1911, terbit koran pertama Sunda bernama Tjahaja Pasoendan yang tebalnya 6o halaman dan berisi antara lain; kesehatan, pertanian dan peternakan, adat istiadat, lelucon dan babad. Koran kedua adalah Papaes Nonoman yang terbit di akhir 1914 (Ajip Rosidi \& Pustaka Jaya (Firm), 200o: 141). Sementara itu Daeng Kanduruan Ardiwinata, 
pada 1 Oktober 1914, menuliskan ada ada empat tijdschrift (surat kabar) Sunda masa itu yakni Tjahaja Pasoendan (sejak Oktober 1912), Panoengtoen Kamadjoean (sejak Maret 1913) Piwoelang Kagoeroean (Papaes Nonoman Nomor 9, Tahun 1, 1 Oktober 1914: lihat juga Ekadjati, 2004: 57).

Kemadjoean (kemajuan) adalah wacana penting yang didiskusikan oleh pribumi Hindia Belanda pada awal abad 20 (Yudi Latif, 2005: 142). Kata-kata yang bermakna 'kemajuan', menurut Takashi Shiraisi, menghiasi banyak perbincangan seharihari (Yudi Latif, 2005: 142). Sayang, studi yang fokus pada wacana kemajuan dalam ruang kultural tertentu mendapatkan porsi yang sedikit. Studi tentang kolonialisme di Indonesia (Hindia) seringkali melupakan bagaimana wacana 'kemajuan' ini dimaknai masyarakat pribumi yang kala itu belum menyatu menjadi 'Indonesia'. Artinya, studi kolonialisme di Indonesia tidak memberi kemungkinan bahwa makna kemajuan tidaklah tunggal.

Istilah Kemadjoean juga digunakan pribumi Sunda. Hampir setiap tulisan dalam Papaes Nonoman, surat kabar yang diterbitkan oleh kelompok etnis Sunda Paguyuban Pasundanpada1913/1914misalnya, mengandung istilah 'kemadjoean'. Namun, studi seputar kolonialisme di Sunda awal abad 20 juga masih banyak memfokuskan diri pada sejarah institusi politik, utamanya berdirinya Paguyuban Pasundan pada 1913/1914 seperti penelitian Ekadjati (2004) dan Soeryawan (1990). Ironisnya, penelitian tersebut -Ekadjati misalnya, dilakukan dengan bersumber dari teks surat kabar, yang semestinya dapat juga dilakukan oleh penelitian dari disiplin komunikasi atau studi media.

Tulisan ini berusaha mengisi kekosongan studi tentang wacana 'kemajuan' di Hindia Belanda pada awal abad 20, khususnya dengan pendekatan kultural. Tulisan ini mempunyai dua pertanyaan besar. Pertama, bagaimana istilah 'kemajuan' ini dipahami, diinteraksikan dan dinegosiasikan oleh masyarakat Sunda? Kedua, adakah kekhususan dalam istilah 'kemajuan' dalam kelompok etnis Sunda, sehingga wacana kemajuan di Hindia Belanda awal abad 20 tidaklah bermakna tunggal?

\section{METODE}

Untuk menjawab pertanyaan tersebut, penulis menggunakan media cetak Sunda sebagai sebuah rekaman. Pertanyaan yang diajukan bagaimana istilah kemajuan dipahami masyarakat Sunda kala itu?

Saya memilih surat kabar Papaes Nonoman (berikutnya akan disingkat sebagai $P N$ ) sebagai lokus penelitian karena ia merupakan surat kabar yang dikelola oleh Paguyuban Pasundan, organisasi kebangsaan yang lahir di Sunda. $P N$ terbit dari tahun 1914-1919. Tulisan ini membatasi beberapa teks terpilih artikel $P N$ dari tahun 1914-1917.

Lebih jauh tulisan ini memperlakukan istilah kemajuan sebagai diskursus atau wacana. Saya menggunakan metode analisis wacana Michel Foucault dimana wacana berarti sebuah praktik/pernyataan yang diatur (M Foucault \& A Sheridan, 1972: 80). Mills (2007) menuliskan bahwa analisis wacana Foucaultian mempertimbangkan bagaimana relasi kebenaran, kuasa dan pengetahuan.

Wacana terbangun oleh sistem pengetahuan atau episteme. Wacana kemajuan dalam masyarakat Sunda berarti merefleksikan bangunan pengetahuan mengenai kemajuan; siapa yang berhak mendefinisikan kemajuan? Apa institusi dan atau praktik yang ditunjuk sebagai kemajuan? Bagaimana masyarakat sunda dalam apa yang disebut sebagai 'maju' itu?

\section{HASIL DAN PEMBAHASAN}

\section{Surat Kabar Papaes Nonoman dan Konteks Sosial Politik Hindia Belanda Awal Abad 20}

Papaes Nonoman adalah surat kabar yang diterbitkan Paguyuban Pasundan, organisasi kebangsaan Sunda yang berdiri tahun 1913/1914 (Ekadjati, 2004; Soeryawan, 1990; Erawan (ed). 200o). Namun PN tidak akan dibicarakan hanya sebagai sebuah 
representasi produsen diskursus-nya yakni Paguyuban Pasundan. PN dalam penelitian ini diperlakukan bukan hanya sebagai representasi kegiatan Paguyuban Pasundan, melainkan praktik kesundaan dalam kurun waktu tertentu dan mempunyai gugus pengetahuan tertentu. Koran ini merupakan arsip bagaimana kelompok etnis Sunda membicarakan dirinya pada awal abad ke20.

Pertama kali terbit 1 Februari 1914, ia dinamai Papaes Nonoman karena "mengharap berkah hadits Rasululloh: perhiasan perempuan adalah senyuman, perhiasan lelaki muda adalah ilmu" (ngalap barkah kana hadis Rasoelloeloh: "papaes istri goemoedjeng, papaes pameget nonoman elmoe)" (PN, Nomor 1, 1 Februari 1914; Pihatoer Directie).

Sesuai keterangan di sampulnya, ia diterbitkan sebulan sekali. Pada tahun kelima, setelah pertengahan tahun 1918, $P N$ berubah nama menjadi Sora Pasoendan. Namun nama Sora Pasoendan ini hanya bertahan beberapa bulan. Senin 17 Februari 1919, pada terbitan pertama di tahun keenam, nama Pasoendan tertera di sampul surat kabar tersebut. Nama baru itu diiringi dengan periode terbit yang baru pula, dari sebulan sekali menjadi tiap minggu.

$P N$ sendiri membahas banyak ragam dan tidak melulu soal Paguyuban Pasundan. Isu yang dibahas misalnya adalah bahasa, pengetahuan ekonomi, isu perempuan, catatan perjalanan, masalah sosial politik seperti kasus Cimareme Garut pada Juli 1919 (SI Afdeling B), organisasi dan lain-lain.

Lebih jauh, $P N$ terbit sesudah dikeluarkannya Undang-Undang Desentralisasi 1903 yang menyerahkan kewenangan pusat kepada badan-badan pemerintahan di daerah. Lewat undangundang tersebut berdirilah Gemeente (Kotapraja) tahun 1905 (Erawan (ed), 2003: 78-79). Desentralisasi ini sendiri adalah praktik dari pernyataan Conrad Theodorevan Deventer pada tahun 1899 dalam artikelnya yang terkenal 'Een Eereschuld' (Utang Budi) yang kemudian diteruskan pidato Ratu Wilhelmina pada tahun 1901, yang mengawali apa yang dinamakan sebagai 'Politik Etis' (Nagazumi, 1989: 27-28).

Walaupun pidato tersebut menekankan kesejahteraan pribumi Kristen, perhatian kemudian meluas meliputi seluruh penduduk pribumi. Namun yang menjadi catatan penting adalah meski terkesan pidato ini penuh moral, namun ia tetap memosisikan keunggulan Belanda. Dengan begitu, apa yang dinamakan politik etis pada dasarnya adalah usaha pem-Barat-an atau pem-Belanda-an. Politik etis, menurut Nagazumi (1989: 27-28) pada dasarnya bertujuan rangkap: pertama, meningkatkan kesejahteraan penduduk pribumi; kedua, berangsur-angsur menumbuhkan otonomi dan desentralisasi politik di Hindia Belanda. Meski demikian pada dasarnya fokus pertama pemerintahan kolonial adalah pada masalah desentralisasi. Di sinilah kemudian pendidikan/pengajaran melalui sekolah dan buku-buku dikembangkan, dimana tujuannya hanyalah untuk memenuhi kepentingan administratif kolonial.

Di Sunda, menurut Moriyama (2003), sekolah dan percetakan buku-buku dimulai sejak 1850-an. Kita akan melihat, sekolah dan buku-buku sebagai kepentingan kekuasaan kolonial ini, bekerja dan menubuh dalam pribumi Sunda dengan memanfaatkan wacana kemajuan.

\section{Kemajuan: Pemujaan Terhadap Belanda}

Sebagaimana terjadi di Jawa, Minangkabau dan daerah Hindia lainnya, kemajuan yang didiskusikan masyarakat Sunda kala itu dianggap bersumber dari Belanda. Sebab kemajuan biasanya diterjemahkan sebagai 'sekolah' atau 'bukubuku'. Namun kemajuan yang bersumber dari Belanda itu, tidak dianggap dari Belanda -sehingga ditolak, melainkan dianggap bagian dari proses menjadi orang Sunda

Tulisan pertama mengenai 'kemajuan' salah satunya datang Soeradiwidjaja dari Kweekschool (Hoogere Kweek School, atau sekolah guru atas) Bandung;

Kanjeng Goevernment terlihat jelas maksudnya untuk memajukan orang 
pribumi, menuntun supaya orang pribumi tambah pengetahuannya. Mungkin saja sebabnya, karena dia (Kanjeng Goevernment pen.) sekarang butuh (terdesak pen.), umpama hendak memerintahkan pekerjaan atau mengurus ke orang yang tahu serta mengerti aturan masalah yang dimaksudkannya lebih mudah ketimbang memerintah kepada orang yang 'malangmang-mulungmung', tidak tahu perkaranya. ( $P N$ Nomor 1, Tahun 1, 1 Februari 1914: Pihatoer ka oerang priboemi di Pasoendan)

Kandjeng Goevernment katjida pisan maksadna kana ngamadjoeken oerang priboemi, noengtoen soepaja oerang priboemi nambahan pangartina. Ari margina panginten bae, tina koe andjeunna katoong, oepama rek barang titah digawe atawa oeroes-oeroes $\mathrm{ka}$ djelema noe njaho sarta ngarti kana atoeranana perkara anoe dimaksoed koe andjeunna, sokleuwihentengbatannitah ka anoe malangmang-moeloengmoeng, teu njaho prakprakanana.

Kemajuanmenurutteksdiatasbersumber dari Kanjeng Goevernment. -sebuah sebutan bagi pemerintah Belanda. Kemajuan adalah keinginan dan inisiatif pemerintah Belanda dengan tujuan mempermudah pekerjaan pemerintah Belanda. Kemajuan diakui menurut kacamata Belanda dan oleh karenanya diinisiasi Belanda, namun hal itu bukan lagi milik Belanda ketika istilah Kanjeng Goevernment digunakan untuk memposisikan Belanda. Istilah Kanjeng Goevernment adalah percampuran dari istilah 'Kanjeng' dan istilah Eropa 'Goevernment'. Belanda yang merupakan bangsa yang lain tidak dikenali sebagai bangsa lain, melainkan diposisikan sebagai 'kanjeng', atau bagian dari 'pribumi'.

Kemajuan dianggap bersumber dari Belanda, maka kemajuan pun didefinisikan dengan pengetahuan Belanda/Eropa.

Bagaimana akalnya supaya kita bisa maju, (apakah dengan) cara orang lain? Orang lain sama saja umatnya Tuhan....
Kenapa bangsa lain seperti bangsa eropa, amerika, jepang dst terlihat sangat meninggalkan kita dalam hal kemajuan?...Kalau kita meniru cara orang lain yang sudah maju, mungkin kekayaan kita bisa sama, atau bahkan lebih.

Kalau satu bangsa sudah punya dua perkara, yaitu;1) sadar ke bangsa sendiri; 2) sadar ke tanah air sendiri, maka dia bisa maju... Kangdjeng Gouvernement sudah sangat berusaha menuntun kepadahal-hal (menyangkut) kemajuan bangsa kita. Buktinya sekolah-sekolah sekarang diperbanyak... (PN Nomor 3, Tahun 1, 13 Maret 1914: Pamanggihna Anoe Ngarang)

....koemahaatoehakalna, seopajaoerang bisa madjoe teh, tjara batoer? Toer eta teh saroea bae pada umat pangeran... naha atoeh ari bangsa sedjen mah, saperti bangsa Eropa, Amerika, Djepang (japan)dstkatjidapisan ninggalkeunana oerang tina kamadjoean teh...lamoen oerang noeroetan tjara batoer noe geus maradjo, meureun kakajaan oerang teh bisa saroea, entong leuwih teh....Lamoen 1 bangsa geus ngabogaan ieu doea perkara, nja eta; 1) Nationaliteitsgevoel (njaah ka bangsa sorangan), djeung 2) Vaderlandsliefde (njaah $\mathrm{ka}$ tanah sorangan) kakara oerang bisa madjoe... Kangdjeng Gouvernement katjida pisan ajeuna noengtoenna tina hal kamadjoean ka bangsa oerang, boektina sakolaz dina waktoe ieu katjida pisan dilobaanana.

Kemajuan di jaman itu berarti 'sekolah' yang diperbanyak Kangdjeng Gouvernement sebagai 'penuntun' pribumi. Artinya kemajuan didefinisikan dengan pengetahuan Belanda, dan bukan orang Sunda. Namun Sekolah sebagai tanda kemajuan tidaklah dianggap hasil meniru bangsa lain sepanjang ia dilandasi oleh apa yang disebut sebagai kesadaran 'berbangsa' dan 'bertanah air'. Tulisan itu meyakini bahwa sekolah hadir untuk pengetahuan, karena bangsa lain dapat maju karena pengetahuan.

Sebuah tulisan berjudul 'Na Enja!' (Nah Iya!) menggambarkan bagaimana wacana 
kemajuan sebagai ruang yang memposisikan masyarakat sunda untuk mengubah dirinya sesuai dengan cara pandang kolonial/ Belanda:

Tidak lama kemudian ada seorang Belanda datang kesitu...rupa-rupanya dia agak simpati ke orang Hindia, buktinya setelah agak lama bercerita, dia kemudian mengatakan: "sayangnya, kemajuan bangsa kamu itu banyak sekali halangannya, halangannya adalah dari bangsa kamu sendiri saja (PN No.1 \& 2 Tahun 1917; Na Enja!)

..teu lila djol aja hidji walanda datang $\mathrm{ka}$ dinja...roeparna manehna teu rada oge njaah ka Indie teh, boektina barang geus lila njaritana, toeloej ngomong kieu; "Handjakal pisan kamadjoean bangsa maneh teh loba pisan halangana... Panghalangna teh ngan bangsa maneh keneh bae"

Halangan dalam kemajuan adalah dari bangsa Sunda sendiri, maka yang harus berubah dalam pertemuan Sunda dengan kolonial adalah orang Sunda dan bukan sebaliknya. Belanda adalah yang maju, jadi tidak perlu berubah. Orang Sunda, dalam teks di atas, sadar mereka 'harus sama' dengan 'sumber kemajuan'. Subjek Sunda harus belajar cara baru dan barangkali harus menghilangkan cara lama yang bisa jadi dianggap 'penghalang' untuk menjadi sama dengan sumber kemajuan.

Sebab kemajuan adalah berasal dari Eropa maka bahasa kemajuan adalah bahasa Eropa, terutama bahasa Belanda. Tak ayal jika Papaes Nonoman menyediakan rubrik berjudul "Diadjar basa Walanda teu make goeroe (diajar bahasa belanda tanpa guru)" yang ditulis oleh seorang berinisial W. Rubrik itu muncul pertama kalidi $P N$, Nomer 6 tahun 1916. Dalam mukaddimahnya, penulisnya membubuhi keterangan "Meunang njoetat tina boekoe karangan toean van der Woude" (Didapat dari buku karangan tuan van Der Woude). Praktik lain terhadap pentingnya penguasaan bahasa Belanda adalah sebuah artikel berjudul 'Boewahna Pasoendan' (PN
Nomor 3, Tahun 3, 30 April 1916) yang berisi penjelasan mengenai pelaksanaan sekolah Bahasa Belanda di Weltvreden bernama Pasoendawati.

Dalam teks $P N$ nomor 5, tahun 1, 1 Juni 1914: Aoseun Istri Pameget,diakui bahwa bahasa Belanda adalah juga kunci agar dapat membaca banyak buku yang berisi penuntun pada kemajuan. Buku-buku berbahasa Belanda mengajarkan banyak soal keselamatan hidup yang belum ada dalam masyarakat Sunda. Artinya 'keselamatan hidup milik Belanda' dianggap 'cara yang belum ada di orang Sunda'. Memahami cara Belanda dianggap melengkapi yang 'sudah ada', dan sama sekali bukan 'menjadi Belanda'. Alih-alih disebut 'menjadi Belanda', memahami cara Belanda/Eropa barangkali -dengan sangat aneh, dipahami sebagai 'menjadi Sunda'.

\section{Kemajuan: Berpikir dan Hidup dengan Cara Belanda}

Perbincangan cara hidup lama orang Sunda dengan cara baru (cara Belanda) juga didasarkan atas wacana kemajuan. Wacana kemajuan dalam proses ini menjadi legitimasi bagi; 1) penerjemahan cara hidup Belanda, sebab cara Belanda dianggap maju ; 2) pembacaan adat istiadat/cara lama dengan rasionalitas baru; 3) pemosisian cara hidup lama orang Sunda sebagai 'yang tidak maju'.

Papes Nonoman banyak memuat terjemahan cara hidup Belanda. Misalnya $P N$ dalam delapan edisi memuat translasi tatakrama cara Belanda. Penulis berinisial S.K. mengaku mengambil bahan artikel itu dari buku yang ditulis oleh Joenker H. A. Rappard. (PN, No.7 Th. 3. (1916); Tatakarama). Artikel itu dalam dua edisi berjudul 'Adat tata krama Bangsa walanda beunang Njoetat tina boekoe Basa Walanda' (Adat tata krama bangsa Belanda didapat dari Buku Basa Belanda). Namun di nomor selanjutnya ia hanya berjudul 'Tatakarama' yang memposisikan bahwa tatakrama produk Belanda tidak dilihat lagi sebagai produk 'dari luar'. 
Peran wacana kemajuan dalam pembacaan adat-istiadat dengan rasionalitas baru misalnya dalam soal tahayul.

Tahayul itu disebut oleh orang Sunda sebagai bid'ah, yaitu kepercayaan manusia kepada gaib (yang tidak ada buktinya) seperti; 1) percaya kepada hantu-hantu; 2)percaya kepada mimpi; 3)percaya kepada yang keramatkeramat; 4) percaya kepada jampi atau kesaktian...Kepercayaan kepada yang bid'ah itu susah sekali dihilangkannya.. rupanya sudah menjadi darah, jadi daging, atau sudah menjadi kesenangan di hatinya, meski tidak kurang-kurang orang yang pintar yang ahli berpikir memaparkan nasehat, serta menjelaskan kalau kepercayaan tersebut kurang baik.... ( $P N$ Nomor 2, Tahun 1, 1 Maret 1914: Tahajoel (een soort bijgeloot) )

Ari tahayoel teh disebatna koe oerang Soenda mah bid'ah, nja eta kapertjajaan djelema ka noe bangsa gaib (ka noe henteu aja boektina); sapertos: I) pertjaja kana djoerig-djoerig; II) pertjaja kana impian;III) pertjaja kana kramatkramat;IV)pertjajakanadjampeatanapi kana kasaktian... Eta kapertjajaan kana bid'ah sesah pisan dileungitkeunana... roepina parantos djadi getih, djadi daging, atanapi parantos njajang dina hatena, sanadjan teu kirang-kirang anoe palinter noe ahli mikir maparin nasehat, sarta nerangkeun jen kapertjajaan kitoe tah kirang sae...Ajeuna badenerangkeun sekadarnya...tina perkawis bid'ah, noe mawi ngadjadikeun kamoendoeran orang priboemi...

Tahayul adalah bid'ah, sebuah istilah agama Islam yang merujuk pada tindakantindakan yang tidakada di jaman Muhammad hidup tapi dipraktikkan kemudian dan dekat dengan makna yang negatif atau sesat -biasanya dengan anggapan bahwa tindakan itu tanpa didasari dari pedoman nabi. Gagasan tahayul adalah bid'ah mungkin sudah biasa di jaman itu, namun barangkali menjadi luar biasa ketika tahayul ikut diberi label penyebab 'kemunduran pribumi' - sebuah oposisi dari 'kemajuan'.

Sementaraitu DKArdiwinata membahas apa yang disebutnya 'kapamalian' (baca; kepercayaan terhadap pantangan/pamali). Ia menulis "Sekarang saya mau bertanya ke semua warga Pasundan, karena sekarang kita sudah berada di jaman kemajuan, mengapa kapamalian itu harus dipakai oleh kita atau dibuang?" (PN Nomor 11, Tahun 1, 1 Desember 1914: Poesaka Anoe Toeroen Temoeroen). Dalam tulisannya, DK Ardiwinata mengatakan kepercayaan terhadap hari naas di kalangan orang Sunda jadi halangan besar terhadap kemajuan, “...sebab jaman sekarang kalau hendak bepergian harus turut pada waktu keberangkatan kereta api yang tidak bisa ditunda-tunda (sabab alam ajeuna lamoen rek njajabaan kapan koedoe noeroetkeun kana inditna kareta api, anoe teu beunang pisan diengke-engke)" (PN Nomor 11, Tahun 1, 1 Desember 1914: Poesaka Anoe Toeroen Temoeroen).

Dalam teks di atas cara lama didekati dengan pendekatan yang rasional, penerjemahan praktik lama dengan cara berpikir baru. Modus dari gaya translasi tersebut adalah praktik lama menjadi tidak berguna ketika seseorang paham cara berpikir yang baru.

Pemosisian cara hidup lama sebagai yang tidak maju misalnya terdapat dalam cara penulis-penulis di $P N$ memperbandingkan dokter dengan dukun.

Pengenalan ilmu kedokteran memenuhi hampir seluruh edisi $P N$ tahun 1914 misalnya bahasan soal Malaria berjudul 'Kawarasan Badan' (Kesehatan Badan) atau 'Hal Noeloengan noe katjilakaan samemehna datang doktor' (Masalah pertolongan pada korban kecelakaan sebelum datang dokter). Meski, barangkali hal ini dapat dilihat karena banyak pengurus $P N$ adalah mahasiswa STOVIA (School tot Opleiding van Indische Artsen/ Sekolah Pendidikan Dokter Hindia), sekolah kedokteran masa itu, yang mempunyai pengetahuan kedokteran.

Untuk mengenalkan dokter, diskusi yang terjadi dalam Papaes Nonoman kemudian memunculkan oposisi 'dukun' sebagai 'yang 
lama'. Dukun tidak selalu sama dengan dokter, tetapi barangkali karena sama-sama menghadapi tubuh, maka dukun dianggap dapat menerjemahkan dokter -sebuah realitas yang baru dikenali.

Muncul masalah, wacana kemajuan kemudian menyingkirkan dukun untuk mengangkat dokter. Mulanya dukun hanya dianggap 'tidak bersih' pada kasus pengobatan sunat:

Umpama anak kita disunat oleh dukun tidak oleh dokter bagusnya mintalah obat ke dokter, tapi baiknya disunat juga harus oleh dokter pribadi, seringnya karena pisau dukun sangat tidak bersih (steril), malah jadi penyakit yang sangat menyulitkan seperti: borok, kekep (tetanus), dst ( $P N$ Nomor 1, Tahun 1, 1 Februari 1914; Roepi-roepi Piloeangeun)

Oepami moerangkalih disepitan koe doekoen henteu koe doktor sae njohoenkeun landongna bae ka doktor, nanging ari saena mah disepitan oge kedah koe doktor pribados, margi sering-sering koe lantaran peso doekoen teu beresih (steriel) pisan, matak djadi kasawat noe sesah pisan kajaning: borok, kekep (tetanus), s.std

Lalu berikutnya sebuah artikel di $P N$ Nomor 10, 31 Oktober 1915 mempermasalahkan kepercayaan kepada dokter dan dukun dalam masyarakat Sunda:

Apa sebabnya masih banyak orang Sunda yang minta bantuan kepada dukun? Sebabnya sudah tentu banyak seperti; 1) tidak berani, karena dokter adalah dari kaum menak/ningrat; 2) tidak ada ongkos, karena takut harus membayar; 3) tidak percaya kepada ilmu dokter. Menurut pikiran penulis, (sebab) yang paling berat adalah hanya "tidak percaya kepada dokter"...

Sudah tentu ada dukun yang benar yaitu yang sudah banyak pengalaman perihal obat, tapi dukun yang seperti itu sangat langka. Paling banyak adalah dukun yang hanya bisa bicara...Dokter sebodoh-bodohnya sudah tentu lebih tahu ketimbang dukun. (PN Nomor 10, Tahun 2, 31 Oktober 1915; Kawarasan Badan)

Koe naon margina noe matak seueur keneh bae oerang Soenda noe marenta toeloeng ka doekoen? Ari sababna mah geus tangtoe rea saperti; 1 )heunteu wani, da ari doktor mah kaseboetna menak;2) henteu aja ongkosna nja eta tina sieun koedoe majar; 3)henteu pertjaja kana elmone dokter. Pikiran anoe ngarang noe pangbeurat-beuratna mah ngan ieu "teu pertjaja ka dokter"...Geus tangtoe aja doekoen noe bener nja eta koe geus rea loeangna tina hal tatamba, tapi doekoen noe kitoe langka pisan. Pangreana nja eta bangsa doekoen noe bisa ngomong...doktor sabodo-bodona oge geus tangtoe loewih kanjahona ti batan noe doekoen

Teks di atas berusaha membangun kepercayaan kepada dokter dengan berusaha mempermasalahkankepercayaanmasyarakat Sunda kepada dukun. Meski kalimat di atas mengungkapkan ada dukun yang benar -dengan syarat sudah banyak pengalaman perihal obat dan itupun jumlahnya sangat langka, dukun diidentifikasi sebagai 'orang yang hanya bisa bicara, bukan mengobati'. Sementara dokter, meski bodoh, dianggap 'lebih tahu' dan kemudian 'lebih benar' ketimbang dukun. Dokter adalah produk kolonial, dan jika dokter kini dianggap lebih tahu ketimbang dukun, maka cara baru melihat tubuh orang Sunda yang merupakan produk kolonial itu dianggap 'lebih benar' ketimbang cara lama.

\section{Kemajuan: Terbebas dari Pengaruh Jawa}

Salah satu fungsi wacana kemajuan awal abad 20 yang khas di Sunda adalah sebagai instrumen mengenali dan membebaskan diri dari pengaruh etnis Jawa. Yang menarik adalah kisah Pasundan Bubat yang menjadi narasi pembedaan Sunda dari Jawa di jaman modern sekarang (Moriyama. 2003) tidak terdapat dalam tulisan penulis-penulis Sunda di $P N$. Wacana kemajuan kala itu memproduksi pembedaan etnis Sunda dan 
etnis Jawa berdasar aturan-aturan dalam wacana kemajuan itu sendiri. Pembedaan dengan etnis Jawa oleh orang Sunda terkait erat dengan praktik kemajuan yakni sekolah dan buku.

Wacana kemajuan memposisikan Jawa sebagai bagian (atau penyebab) dari kemunduran orang Sunda. Ada tiga hal yang akan disinggung makalah ini. Pertama, relasi Jawa dengan pesantren yang dianggap kurang maju ketimbang sekolah. Kedua, relasi budaya Jawa dengan menak Sunda yang dianggap kaum kolot di jaman kemajuan. Ketiga relasi Jawa dalam perkembangan produk literatur Sunda.

Kemajuan, yang lebih kurang dipahami sebagai sekolah, mau tak mau menghadirkan 'pesantren', institusi pengetahuan yang sudah ada sebelum sekolah didirikan pemerintah penjajah. Sebagaimana aturan dalam wacana kemajuan, pesantren dianggap sebagai 'cara yang lama', sehingga ia dinilai sebagai bukan bagian dari kemajuan.

Yang diajarkan di pesantren itu sudah tentu hal kepandaian dan masalah adat, sekarangpun di jaman sekolahan masih ada saja pesantren seperti itu. Tentu ada manfaatnya untuk anak kita, tetapi guru-guru pesantren tidak sama kepandaiannya serta belum tentu bagus lakunya! Apalagi kalau gurunya kurang pengertian terhadap alam dunia, yang suka menyebut semua haram itu. (Bilang) Jangan menerima pengetahuan atau harta dari bangsa lain, tapi kalau menerima uang yang dicetaknya di Eropa boleh.... (PN Nomor 8, Tahun 1916: Hal ngoeroes boedak (Opvoeding))

Koe sabab di doenja hal kapinteran madjoe, djol aja djelma noe sanggoep mere pangadjaran ka baroedak, nja eta goeroe pasantren anoe djadi goeroe dina eta pasantren nja eta djalma noe geus meunang pangadjaran ti tempat sedjen, djadi noe katendjo leuwih pinter ti batan djelema-djelema oerang dinja. Anoe diajarkeun dina eta pasantren geus tangtoe hal kapinteran djeung hal adat deui bae, ajeuna oge di djaman sekolaan aja keneh bae eta pasantren teh, tangtoe aja ari mangpaatna keur baroedak oerang mah, ngan handjakal ari goeroe-goeroe pasantren mah tue asa saroea kapinteranana sarta teu atjan poegoeh hade lampahna! Komo lamoen goeroena koerang pamanggihna mah koerang ngartina di hal alam doenja noe sok njeboet sagala haram tea oelah nampa pangarti atau banda ti bangsa sedjen, tapi ari nampa doeit mah noe ditjitakna di Eropa meunang..

Apa yang menarik dalam teks di atas adalah pesantren dinilai belum tentu dapat mengantisipasi masalah 'jaman sekolahan', ketika guru-gurunya banyak mengandalkan penilaian agama. Penilaian terhadap pesantren ini berkebalikan dengan laporan Chijs pada tahun 1864, ketika masa awal sekolah didirikan. Kala itu, menurut Chijs masyarakat Hindia Belanda enggan mengirimkan anak-anak mereka ke sekolah, karena sekolah dianggap 'kafir' (Moriyama, 2003;79). 'Kemajuan',olehkarenanya, berhasil membebaskan sekolah dari pengkafiran; sebuah identitas yang barangkali diberikan pengetahuan sebelumnya yang disusun melalui institusi pesantren.

Selain dianggap bukan bagian dari kemajuan pesantren banyak dipengaruhi budaya Jawa. Gagasan ini terdapat dalam tulisan Daeng Kanduruan Ardiwinata dalam PN Nomor 5, 1 Juni 1914. Ardiwinata menyatakan bahwa perginya orang-orang Sunda ke pesantren Jawa adalah salah satu sebab tersebarnya bahasa Jawa di Priangan. Logikanya, pesantren yang berada di Jawa dianggap pernah menjadi 'kiblat kemajuan', dengan begitu orang Sunda harus belajar dan menguasai bahasa Jawa.

...ilmu orang priangan didapatkan dari belajar kepada orang Jawa itu tidak hanya bahasanya belaka, tapi agama, ilmu kelahiran/duniawi, ilmu perbintangan, ilmu firasat, caturrangga, ilmu pertanian, kekayaan, semuanya dari sana. Kebiasaan orang Priangan harus saja belajar di pesantren, sampai di Dasarema dan Ponorogo, cara berceritanya sudah laksana di Makah dan Madinah saja. Kebanyakan 
yang belajar di pesantren, diajar ilmu syara'/hukum saja, tapi banyak juga diajar ilmu tarekat dan hakikat yang dibarengi dengan ilmu duniawi. Mereka yang diajar ilmu hakikat, yang kembali (ke Priangan) suka membawa primbon, isinya ilmu-ilmu agama dan ilmu duniawi...dituliskannya di kertas daluang, aksaranya arab, bahasanya tentu bahasa Jawa...Yang mengaji ilmu syara', sepulang ke Priangan sudah lebih banyak kitab-kitab Arab cetakan Makah untuk mendirikan pesantren, tapi mengajarnya dengan bahasa jawa saja... (PN Nomor 5, Tahun 1914: Basa Djawa di Priangan)

Elmoe oerang Priangan beunangna goegoeroe ti oerang Djawa teh lain ngan aksara djeung basana bae, tapi agama, elmoe kelahiran, elmoe palintangan, elmoe pirasat, tjatoerangga, elmoe katanian, kabeungharan babakoena nja ti ditoe...adat oerang Priangan ana malasantren koedoe bae ka Djawa, lantaran di oerang tatjan aja pasantren, nepi ka pasantren Dasarema djeung Panaragan teh ditjaritakeunana geus tjara njaritakeun Mekah Madinah bae. Lolobana anoe malasantren teh diadjar elmoe sjara' bae, tapi loba oge anoe diadjar elmoe tarekat djeung hakekat dibarengankoeelmoekalahiran.Etaanoe dialadjar elmoe hakekat te ana baralik sok marawa paririmbon, eusina nja eta elmoe-elmoe agama djeung kalahiran tea...ditoelisna dina kertas daloeang, aksarana arab, basana tangtoe basa Djawa...anoe ngaraji elmoe sjara tea, sanggeusna datang ka Priangan sarta di oerang geus luwih loba kitab-kitab Arab tjitak ti Mekah pek ngaradegkeun pasantren, tapi ngadjarna mah nja koe basa Djawa bae

Dalam teks di atas, kemajuan mensyaratkan adanya 'keharusan berbahasa'. Pesantren pernah menjadi kiblat kemajuan dan hal itu mensyaratkan 'keharusan berbahasa Jawa'. Ketika pesantren digantikan sekolah -sebuah kemajuan baru, keharusan berbahasa Jawa ikut ditolak dan digantikan keharusan berbahasa Belanda yang dipuja- puji sebagai bahasa yang menghubungkan masyarakat Sunda dengan 'kemajuan'.

Menurut Ardiwinata, sejak 1900 orang Sunda tak peduli lagi pada bahasa Jawa. Sejak kecil mereka harus belajar bahasa Melayu atau bahasa Sunda di sekolah. Kepandaian dari Jawa pun, dinilai agak tidak berguna. Jumlah orang Sunda yang 'mesantren' di Jawa sangat langka. Bahkan seorang Kiai Sunda enggan memaknai ayat Quran dengan bahasa Jawa sebagaimana biasanya. Hanya penikmat wayang atau orang Sunda yang telanjur senang dengan Jawa saja yang dapat berbicara bahasa Jawa, "sekira dari tahun 1900, setelah pengajaran sekolah ditinggikan, anak-anak (Sunda) kelihatannya sudah tidak gemar sama sekali dengan bahasa Jawa. Yang jadi semboyannya adalah 'kaoem moeda' dan 'abad kedua puluh”' (PN Nomor 5, Tahun 1914: Basa Djawa di Priangan).

Selain pesantren, penyebar bahasa Jawa menurut Daeng Kanduruan Ardiwinata adalah kaum menak Sunda. Tata administrasi Mataram yang membawahi Priangan membuat bahasa Jawa tersebar di kalangan menak Priangan. Meski Priangan kemudian diperintah Belanda, para menak masih melanjutkan kebiasaan berbahasa dan beraksara Jawa. Pendek kata, menurut Ardiwinata "bahasa Jawa adalah bahasa menak" (PN No 5 Tahun.1 Juni 1914; Basa Djawa di Priangan) sementara basa Sunda adalah bahasa somah/kuring atau masyarakat biasa. Artinya Jawa merepresentasikan kaum menak Sunda yang dianggap bukan bagian dari kemajuan. Kelas sosial dalam bahasa Sunda itu, menurut Ardiwinata, mulai berubah hanya ketika tahun 1860-an karena: “... sekolah-sekolah mulai banyak memasukkan kepandaian dari Belanda. Pada pokoknya lantaran jasa Kanjeng Tuan K.F Holle dan lain-lain, setelah di Bandung diadakan sekolah guru tahun 1866" (PN No 5 Tahun.1 Juni 1914; Basa Djawa di Priangan).

Dalam tulisan lain mengenai prosa dan puisi ( $P N$ Nomor 9, Tahun 1, 1 Oktober 1914; "Proza en Poezie") Daeng Kanduruan Ardiwinata menulis bahwa minimnya karya prosa di Sunda adalah karena pengaruh Jawa. Ada satu karya yang bentuknya mirip prosa 
yakni Cerita Sangkuriang, namun tidak dapat disebut sebagai 'buku', melainkan 'primbon'. Kalaupun ada karangan bebas dari masa lalu adalah 'wawacan' yaitu "cerita yang ditembangkan/dilagukan, seperti di Jawa”.

Mengapa prosa sangat jarang? Ardiwinata menjawab, "karena adat orang Jawa dan orang Sunda, hinga sekarang, jika hendak mengarang masalah pelajaran atau ilmu-ilmu, baik agama maupun lahir, sering ditembangkan saja”. Setelah 'kanjeng Gouvernement' mencetak buku pada 1866 untuk pengajaran di sekolah. mulailah muncul prosa. Ardiwinata meramal bahwa tembang yang berasal dari Jawa akan kalah.

“...Sebenarnya lebih bagus prosa dan puisi. Coba jika orang Sunda sudah seneng membaca...dan sudah banyak buku-buku prosa yang bagus seperti di Belanda, tentu bisa ditemukan kenikmatan membaca. Tentu tembang nanti kalah. Tapi tembang tidak akan hilang, dan jangan dihilangkan, sebab ia adalah pusaka dari guru kita yang kedua, yaitu orang Jawa...

Dalam teks di atas, kemunduran prosa Sunda dihubungkan dengan pengaruh 'kelisanan' Jawa dalam literatur Sunda. Tradisi tembang yang merupakan bagian kelisanan bukanlah disebabkan oleh masyarakat Sunda sendiri, melainkan karena pengaruh Jawa sebagai 'guru kedua'. Istilah 'guru kedua' bagi orang Jawa di atas menandai bahwa wacana kemajuan mengantarkan orang Sunda untuk mengenali pengaruh Jawa. Istilah ini sekaligus juga menandai bahwa Jawa tidak lagi menjadi kiblat kemajuan, melainkan Belanda, sebagai 'guru pertama'.

\section{SIMPULAN}

Semua artikel yang ditulis para penulis Sunda di surat kabar Papaes Nonoman banyak menggunakan istilah 'kemadjoean'. Uniknya, tak ada satupun artikel berusaha menjelaskan terminologi kemajuan dengan perspektif kebahasaan. Tak seorang pun penulis Sunda yang tergerak membicarakan kata 'maju' dengan kata Sunda 'paju' yang berarti: "going forward, advancing, guzzling, eating greedily" (Jonathan Rigg, 1862: 333). Oleh karenanya wacana kemajuan sebaiknya dimengerti sebagai praktik wacana, praktik dari pernyataan yang diatur.

Kemajuan oleh masyarakat Sunda biasanya diterjemahkan sebagai 'sekolah' atau 'buku-buku'. Kemajuan oleh karenanya berarti pemujaan terhadap Belanda. Dengan kemajuan, Belanda/Eropa mengenalkan cara hidup yang benar-benar baru bagi masyarakat Sunda. Wacana kemajuan menjadi dasar bagi perbandingan cara hidup lama orang Sunda dengan cara baru (cara Belanda), dimana cara berpikir dan hidup ala belanda dianggap maju, sementara cara hidup lama orang Sunda sebagai 'yang tidak maju'. Pemahaman wacana kemajuan dalam masyarakat Sunda ini sesuai dengan kepentingan kolonial Belanda. Dengan wacana kemajuan, kepentingan kolonial akan tersedianya tenaga administratif tidak saja 'dituruti' masyarakat Sunda sebagai regulasi terhadap masyarakat terjajah, tetapi malah dianggap sebagai bagian dari cara 'menjadi Sunda'.

Secara khusus wacana kemajuan di kalangan masyarakat Sunda kala itu memposisikan Jawa sebagai bagian (atau penyebab) dari kemunduran orang Sunda. Oleh karenanya, kemajuan berarti juga upaya membebaskan Sunda dari pengaruh Jawa. Jawa, menurut orang Sunda kala itu, merepresentasikan 'cara lama', cara yang tidak maju. Hal ini menjadi ciri khusus bagaimana praktik wacana kemajuan di Sunda yang tidak terjadi di ruang kultural lain. Dengan demikian apa yang dipahami sebagai kemajuan dalam masa Hindia Belanda tidaklah tunggal, melainkan terkait dengan ruang kultural dimana kemajuan dibicarakan atau dikomunikasikan. 


\section{DAFTAR PUSTAKA}

Ekadjati, Edi S. 2004. Kebangkitan Kembali Orang Sunda: Kasus Paguyuban Pasundan 1913-1918. Bandung: Kiblat Buku Utama

Erawan, Memed (ed). 20oo. Paguyuban Pasundan; Kiprah dan Perjuangannya dari Zaman ke Zaman (1914-200o). Bandung. Pengurus Besar Paguyuban Pasundan

Foucault, M. \& Sheridan, A.. 1972. The Archaeology of Knowledge. New York: Pantheon Books.

Latif, Yudi. 2005. Inteligensia Muslim dan Kuasa: Genealogi Inteligensia Muslim Indonesia abad ke-2o. Bandung: Mizan.

Mills, Sara. $\quad 1997 . \quad$ Discourse. London\&Newyork. Routledge.

Moriyama, Mikihiro. 2003. Semangat Baru: Kolonialisme, Budaya Cetak, dan Kesusastraan Sunda Abad 19. Jakarta. Kepustakaan Populer Gramedia

Nagazumi, Akira. 1989. Bangkitnya Nasionalisme Indonesia: Budi Utomo 1908-1918. Jakarta. Pustaka Utama Grafiti.

Ricklefs, M. C. 2001. A History of Modern Indonesia Since c.1200. Basingstoke: Palgrave.

Rosidi, A., \& Pustaka Jaya (Firm). (2000). Ensiklopedi Sunda: Alam, Manusia, dan Budaya, Termasuk Budaya Cirebon dan Betawi. Jakarta: Pustaka Jaya.

Soeryawan, R. Djaka. 1990. Sejarah Berdirinya Paguyuban Pasundan. Bandung. Lembaga Kebudayaan Universitas Pasundan Bandung

Papaes Nonoman. 1914-1919, Orgaan Van De Vereeniging Pasoendan. 3 Bundel. Koleksi Perpustakaan Nasional 
INFORMASI Kajian Ilmu Komunikasi Volume 45. Nomor 2. Desember 2015 